\title{
Chelant-Induced Phytoextraction of Heavy Metals from Contaminated Soils: A Review
}

\author{
Xunguang Bian ${ }^{1,2,3}$, Jun Cui ${ }^{1,2}$, Boping Tang ${ }^{1,2}$, Li Yang ${ }^{1,2 *}$ \\ ${ }^{1}$ Jiangsu Provincial Key Laboratory of Coastal Wetland Bioresources and Environmental Protection, \\ Yancheng Teachers University, Yancheng, Jiangsu, China \\ ${ }^{2}$ Jiangsu Key Laboratory for Bioresources of Saline Soils, Yancheng Teachers University, \\ Yancheng, Jiangsu, China \\ ${ }^{3}$ School of Ocean and Biological Engineering, Yancheng Teachers University, Yancheng, Jiangsu, China
}

Received: 23 September 2017

Accepted: 14 December 2017

\begin{abstract}
Chelant-induced phytoextraction is considered an ideal remedial technique for removing heavy metals from contaminated soils. However, it can increase the risk of adverse environmental effects due to increased metal mobilization and the persistence of both chelants and metal-chelant complexes for extended periods of time. This paper reviews the mechanism, potential risks, and optimization of chelant-induced phytoextraction of toxic metals from contaminated soils. The advantages and major drawbacks of phytoextraction, along with possible strategies to reducing the risks associated with chelant application, are reviewed. Moreover, the directions for future research on chelant-assisted phytoextraction are briefly discussed. The objective of this paper was to comprehensively review chelant-assisted phytoextraction, and it will provide an effective and safe remediation technology for heavy metal-contaminated soils.
\end{abstract}

Keywords: chelant, heavy metal, soil pollution, phytoextraction

\section{Introduction}

Heavy metal contamination of soils is one of the most serious environmental problems throughout the world. Elevated soil metal concentrations not only affect the activities of soil biota, soil fertility, and crop production, but also threaten human health through ingestion of contaminated food [1-2]. The remediation of heavy metalcontaminated soils is therefore an important challenge that has to be faced with appropriate methods [3].

*e-mail: yangli86716@163.com

A number of techniques, such as ex situ or in situ extraction and immobilization, have been developed to remove heavy metals from contaminated soils. Phytoextraction techniques (using plants to remediate metal-contaminated soils) have become a major research topic in the past 2 decades, as they are low-cost, efficient, and environmentally friendly [4-6]. The success of phytoextraction is dependent on large biomass production and high concentrations of heavy metals in the shoots of plants [7-8]. In order to improve the efficiency of heavy metal accumulation in plant shoots, a few fastgrowing, high-biomass plant species and some chelants have been evaluated for potential use in phytoextraction, as low biomass production and slow growth of the 
hyperaccumulators are the factors that limit this efficiency [9]. Chelant-enhanced phytoextraction of heavy metals from contaminated soils have aroused public concern as a cost-effective and environmentally friendly alternative to conventional techniques of soil remediation, the efficiency of chelant-enhanced phytoextraction depends on metal, plant species, and chelant concentration [10-12]. The aims this technique are to cleanse metal-contaminated soils by inducing plants to accumulate metals in the harvestable parts by adding chelants to the soil [10]. We could then remove the metal-rich biomass from the site and store it in an area where it does not pose a risk to the environment. However, results from studies on the stimulating effects of chelants on shoot metal accumulation in different plant species have been largely inconsistent [7, 13-14]. Moreover, the addition of chelants to the soil can directly or indirectly affect plant health, soil microbial properties, and heavy metal concentrations in both soils and plants [15]. And most of the chelants used in the technique are very expensive. Therefore, the potential threats and the cost of employing chelants for phytoextraction to the environment should be considered.

This paper reviews the use of chelants in assisting in situ phytoextraction of heavy metals from contaminated soils. The recent advancements in research on chelantenhanced phytoextraction are summarized, and recommendations for optimizing this technique are suggested to improve its efficiency.

\section{Phytoextraction}

Plants have a natural propensity to take up metals, which creates the possibility for phytoremediation of heavy metal-contaminated soils. Phytoremediation is defined as the process where various plants are used to degrade, extract, contain, or immobilize contaminants in soil and water, and can be divided into 4 general categories: phytovolatilization, phytostabilization, rhizofiltration, and phytoextraction (Table 1).

Phytoextraction is the uptake of contaminants by plant roots and translocation within the plants. Contaminants are generally removed by harvesting the plants. Some studies have suggested that the plants used for phytoremediation should be fast-growing and easily propagated, with high biomass and a profuse root system, and capable of accumulating high levels of the target metal [16-17]. Hyperaccumulators have a strong absorption and accumulation capacity for heavy metals, when they are present at high concentrations in the external environment. In addition, they can accumulate heavy metals at several times higher than the normal concentration in vivo, even at relatively low metal concentrations in the surrounding environment [1819]. To date, more than 500 plant species from more than 40 genera have been identified as natural metal hyperaccumulators, representing $<0.2 \%$ of all the angiosperms [20-21]. However, a general characteristic of these hyperaccumulators is slow growth and limited biomass production, which limits their phytoextraction efficiency [22-23]. As a result, two strategies for enhancing phytoextraction have been proposed. First, for improving their metal extraction capacities, genetic engineering and modern molecular biology techniques can be used eliminate the drawbacks of the hyperaccumulators [24]. Second, to increase the bioavailability of heavy metals in the polluted soils, which would in turn enhance their uptake by plant roots, chelants can be added to the soil.

\section{Chelant-Induced Phytoextraction}

Heavy metals in the soil are usually present in a combined form with its organic and inorganic components, or as precipitates. Therefore, most of the heavy metals in the soil cannot be directly absorbed by the plants. Chelants have been used as soil extractants to disturb the balance between the solid and liquid phases of contaminates in the soil, increasing the concentration of soluble metals, which is likely to promote the uptake of heavy metals by a high-biomass plant $[14,25]$.

\section{Origin of Chelant-Induced Phytoextraction}

Research on the interactions between chelants and plants began in the 1950s, when chelants were first used in plant nutrition studies. It was found that the application of chelants to the soil could improve the solubility of trace elements, and ameliorate the deficiency of essential nutrients such as $\mathrm{Fe}, \mathrm{Mn}, \mathrm{Cu}$, and $\mathrm{Zn}$ during plant growth [26]. In 1974 Wallace showed for the first time that the application of chelants such as EDTA and NTA to the soil significantly enhances metal accumulation by the plants. Chelants have also been used as soil extractants, as a source of micronutrient fertilizers, and to maintain the solubility of the micronutrients in hydroponic solutions [27].

Table 1. The mechanisms of different process of phytoremediation (Ghosh and Singh, 2005).

\begin{tabular}{|c|c|c|c|}
\hline Types of phytoremediation & Mechanism & Contaminant & Scope of application \\
\hline Phytovolatilization & Volatilisation by leaves & Organics/Inorganics & Volatile contaminants \\
\hline Phytostabilization & Complexation & Inorganics & Mining contamination \\
\hline Rhizofiltration & Rhizosphere accumulation & Organics/Inorganics & Waste water \\
\hline Phytoextraction & Hyper-accumulation & Inorganics & Low-to-medium-contaminated sites \\
\hline
\end{tabular}




\section{Classification of Chelants}

Chelants used in the phytoextraction of heavy metals from contaminated soils can be divided into 2 categories. One is aminopolycarboxylic acids (APCAs), such as ethylene diamine tetraacetic acid (EDTA), ethylene bis[oxyethylenetrinitrilo] tetraacetic acid (EGTA), diethylene triamino pentaacetic acid (DTPA), hydroxylethylene diamine tetraacetic acid (HEDTA), ethylenediamine- N,N'bis(o-hydroxyphenyl) acetic acid (EDDHA), etc. Although these chelants could be effective in enhancing phytoextraction, they have low biodegradability and could pollute the environment. Recently the natural APCAs, such asethylene diamine disuccinate (EDDS) and nitrilo triacetic acid (NTA) in soil phytoremediation processes, has been proposed. Another is the low molecular weight organic acids (LMWOAs), such as citric acid, oxalic acid, and tartaric acid, etc. Compared with the synthetic APCAs, they do not cause leaching of the heavy metals and other environmental risks, owing to their fast turnover in the soil and low toxicity [28].

\section{Mechanisms of Chelant-Induced Phytoextraction}

Although the studies on chelant-induced phytoextraction primarily focus on increasing accumulation, little is known about the mechanisms of heavy metal uptake by the plants.

\section{Metal Activation}

Metals in the soil primarily exist as components of its organic and inorganic constituents, or as precipitates and insoluble compounds. The phytoextraction efficiency is highly correlated with the availability of free metals in the soil. Aminopolycarboxylates contain one or more secondary/tertiary amines and 2 or more carboxylic acid groups, which can form thermodynamically stable polydentate complexes with metals [29]. It has been shown that chelant application to the soil can increase the bioavailability and mobility of metals through desorption of the sorbed species, and the dissolution of $\mathrm{Fe}$ and $\mathrm{Mn}$ oxides as well was the precipitated compounds [27, 30]. The efficiency of the chelants for heavy metal extraction is assessed by their stability constants.

\section{Mechanism of Plant Absorption}

The mechanisms of metal-chelant absorption by the plant roots are not clearly understood. It is unknown whether the metal-chelant complexes are directly absorbed by the plant roots, or dissociation of the complexes occurs prior to their uptake. There are two contrasting theories in this regard. The predominant theory for metal-chelant uptake is the split-uptake mechanism, according to which only free metal ions can be absorbed by plant roots, and therefore, metal-chelant complexes need to dissociate before their absorption [31]. In a hydroponic experiment, Wei et al. [32] found that in the presence of $50 \mathrm{mmol} \mathrm{L}^{-1}$ $\mathrm{Cu}$, the addition of EDDS increased the biomass and the viability of cells in the root tips, while decreasing the relative electrolyte leakage from root cells and the concentration of $\mathrm{Cu}$ in the shoots. The permeability of the endodermal barrier to the $\mathrm{Cu}$-citrate complex might vary between dicotyledonous and monocotyledonous plants, and this has considerable implications for chelantenhanced phytoextraction [33]. On the other hand, the second theory suggests that a few purportedly intact metal-chelant complexes are taken up by the plants [10].

Metal-chelant complexes cannot diffuse across the plasma membrane, as they are too large and polar to move through the plasmalemma lipid bilayer. Therefore,

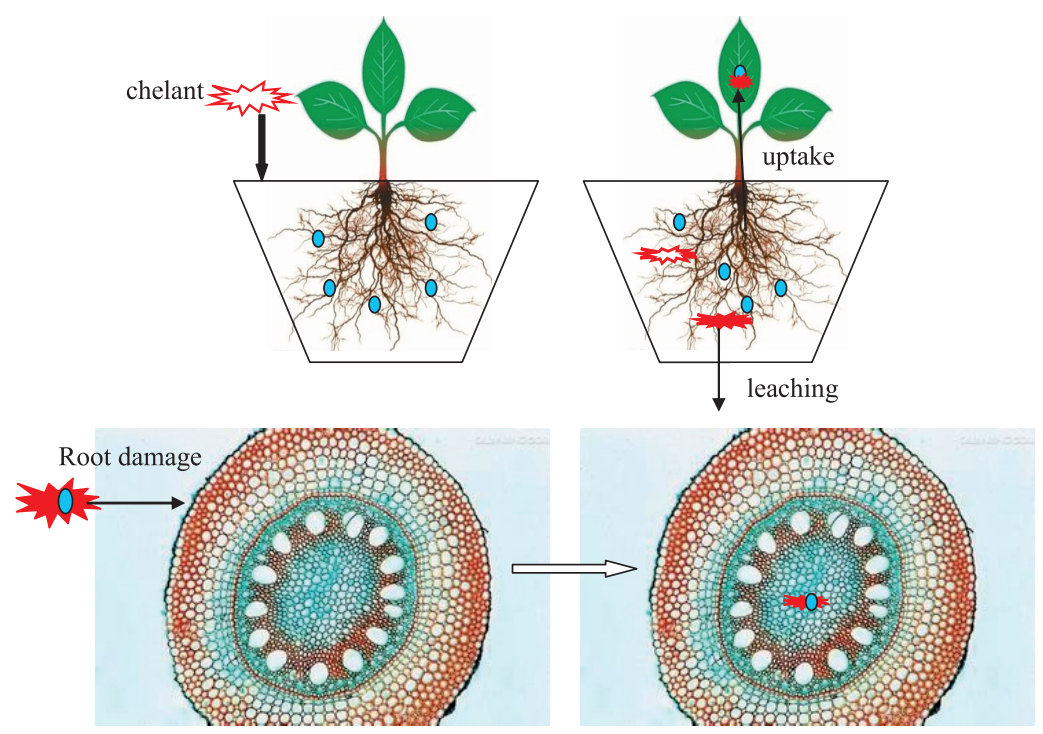

Fig. 1. The schematic representation of the uptake of metal-chelant complexes by plant roots, their translocation upward, and the potential leaching of metals into the deeper soil in the process of chelant-induced phytoextraction (the red star and blue circle represent the applied chelant and the metals in the soil, respectively). 
$\mathrm{Zn}, \mathrm{Cu}$, and $\mathrm{Pb}$ can be absorbed by the plant roots and transferred as a metal-chelant complex [31, 34]. Tian et al. [35] detected Pb-EDTA in the vascular bundles of both leaf and stem tissues in the accumulator plants using synchrotron-based x-ray microfluorescence and powder extended $x$-ray absorption fine structure (EXAFS) spectroscopy. It has been concluded that the uptake of $\mathrm{Pb}$ EDTA by the plant roots is possible at locations where the suberization of root cell walls has not yet occurred and at breaks in the root endodermis and the Casparian strip [36-37]. It has been suggested that the metal-chelant complexes might enter the xylem vessels for translocation to the aboveground plant parts through passive pathways that use transpiration pull as the main driving force [38]. A schematic display of this process is shown in Fig. 1.

\section{Potential Risks Associated with Chelant-Induced Phytoextraction}

\section{Plant Growth}

The addition of chelants could significantly depress plant growth via low seed germination, leaf wilting, chlorosis and necrosis, abscission, shoot desiccation, and reduced transpiration [2, 12, 14]. These deleterious effects vary across different chelants, for instance EDDS and CA had a less negative impact on plants than DTPA (diethylene triamino pentaacetic acid) and EDTA, while EDTA demonstrated the most toxic effects [14]. Luo et al. [39] reported that the plants subjected to combined EDTA and EDDS treatment exhibited a slightly lower biomass compared with those receiving a treatment of only EDTA. In chelant-induced phytoextraction, there are several factors that influence plant growth, the most important ones being chelant/metal molar ratio, mode, and time of chelant application [40], the plant species, and the type and concentration of other heavy metals [7, 13-14].

\section{Soil Biota}

It usually requires several successive crop harvests to fulfill phytoextraction of metals from the contaminated soils. To ensure vigorous plant growth following phytoremediation, it is essential to maintain soil quality [40]. It has been reported that the application of chelants has a negative impact on soil quality [41]. Many studies have reported the adverse effects of chelant-induced phytoextraction on the populations and activity of microorganisms [42], as well as the activity of enzymes [43-45]. However, Sapoundjieva et al. [46] found that the application of EDTA did not have any negative effects on soil microorganisms.

\section{Leaching of Heavy Metals}

Although the accumulation of heavy metals in plants dramatically increases following the application of chelants, it might pose potential risks such as groundwater contamination through the uncontrolled solubilization and migration of the metal-chelant complexes [47]. Various chemical extraction studies based on batch and column techniques have been performed to evaluate the metal leaching risk associated with chelant application to deep soil layers [48-50]. The soluble metal levels increase significantly upon chelanst application [14, 51-52], and the leaching of metals increases with rainfall during chelant-induced phytoextraction [12]. Meers et al. [53] observed that only less than $1.1 \%$ of mobilized metals were effectively accumulated in the plant shoots. The disadvantages of the chelants application are not only related to the increased solubility of the metals but also their low biodegradability in soil.

\section{Residual Effects of Chelants and Metal-Chelant Complexes}

Although chelants are effective in removing metals from the soil, the extended residual time of both chelants themselves and the metal-chelant complexes should be considered [29], as their persistence might continue to cause enhanced toxicity against plants and the soil organisms for a long time. EDTA has been shown to persist for extended periods in soils because of its poor degradability $[2,53]$. Most studies have indicated that the half-life of EDDS in soils is 2-8 days [34, 53-55]. Although EDDS is biodegradable, the risk posed by its residual concentrations for plants and the soil biota remains a concern. Yang et al. [12] reported that no negative growth effects were identified for the second and third crops, which were harvested 81 and 204 days after the EDDS application, respectively, showing that the residual risk associated with EDDS application was limited. EDDS was reported to have degraded fully, 22 days after the EDDS application under field conditions [50]. However, Hauser et al. [56] reported a lower biodegradation rate for EDDS. The degradation of EDDS might be influenced by the dosage applied, soil properties, metal types, and composition [57-60].

\section{Optimizing the Phytoextraction Technique}

The efficiency of phytoextraction has been found to be influenced by many factors. Over the last decade, several authors have highlighted the need to optimize the process of chelant-induced phytoextraction, including selection of the chelant concentration and species, selection of the plant species, methods, and time of chelant applied, design of cropping pattern (co-cropping or rotation), and the irrigation technique.

\section{Choice of Chelants}

The chelant-induced increase in the accumulation efficiency of plants appears to be directly related to the ability of the chelant to dissolve metals [61]. The synthetic APCAs (especially EDTA) have a high affinity for metals, while the affinity of the LMWOAs is low [62]. 
In most cases, EDTA was superior to EDDS in terms of solubilizing $\mathrm{Cd}, \mathrm{Pb}$, and $\mathrm{Mn}$, whereas EDDS was more effective in solubilizing $\mathrm{Cu}$ and $\mathrm{Ni}$ [51]. Several studies have shown that EDTA is not easily biodegraded [10, 40, 49], and that EDTA and metal-EDTA complexes are toxic to soil microorganisms $[15,41]$ and plants $[7$, 9]. As a result, the use of easily biodegradable chelants such as EDDS, MGDA, and NTA has been proposed for soil phytoremediation [38, 59-60, 63]. These easily biodegradable chelants can improve the uptake of metals by plants, with minimal residual effects on the environment [12, 45]. Tsang et al. [64] reported that significant exchange with the sorbed metals on the soil surface resulted in a high degree of resorption of the metal-EDDS complexes. A number of different APCAs have been tested. Chen et al. [65] reported that the order of effectiveness for increasing water-soluble $\mathrm{Cd}$ accumulation at the same dosage was the following: EDTA $>$ DTPA $>$ NTA $>$ citric acid.

Apart from the chelant identity, the chelant concentration is also considered a key factor affecting the efficiency of phytoextraction. The soluble metal content and phytoextraction efficiency increased with the increasing level of EDDS or EDTA added to the soil [9]. However, this does not mean that the amount of bioavailable metals in the soil solution increased with the increasing level of chelants $[2,66]$.

\section{Choice of Plant Species}

For a given chelant dosage during chelant-induced phytoextraction, we can screen for more sensitive species/ cultivars and optimize the growth conditions for those plants to increase phytoextraction efficiency. Different plant species or the same plant species with different culture conditions might result in a significant difference with respect to chelant tolerance and the phytoextraction efficiency of metals $[7,13,15]$. In general, dicots are more sensitive to the application of chelants than the monocots.

The application of chelants could increase the risk of dispersing metal contaminants to groundwater and the surrounding environment [67]. A good approach is using deep-rooted, higher water-use plants or trees to reduce the metal leaching risk through transpiration [51]. Chen et al. [68] reported that $98,54,41$, and $88 \%$ of the initially applied $\mathrm{Pb}, \mathrm{Cu}, \mathrm{Zn}$, and $\mathrm{Cd}$ could get re-adsorbed in the soil owing to the effects of vetivers. Therefore, if highly metal-tolerant plants are intercropped with deeprooted plants (such as eucalyptus camaldulensis or vetiver grass), the metals will be accumulated in the shoots of the metal-tolerant plants, and the leaching of metals would be prevented by the roots of deep-rooted plants [38].

\section{Methods of Chelant Application}

Suitable strategies for chelants application are helpful for optimizing phytoextraction. It has been reported that applying the chelant at a depth near the plant roots leads to a significantly higher accumulation of trace metals by the plants than adding across the entire soil area [11]. The combined application of different chelants or chemicals can greatly improve metal phytoextraction efficiency [38], for instance, the combined application of EDTA and EDDS leads to a higher phytoextraction efficiency of $\mathrm{Cu}$ [69]. These kinds of combinations are based on the interactions between the metals and different chelants, where the solubility of a metal by a chelant can be increased by another chelant via reduction in competition from the other metals in the soil. The chelants, when applied in several small doses, can also result in greater phytoextraction of metal compared with a single dose [47]. We can also use a chemical to destroy the plant root structure, facilitating the direct uptake of metalchelant complexes and their translocation into the shoots. Applying chelants after the plants have attained sufficient biomass is also an option to decrease environmental risks.

In addition, there are several other techniques to optimize phytoextraction. Roots inoculated with metalresistant and plant growth-promoting bacteria can significantly promote the plant growth and $\mathrm{Cd}$ uptake by the plants [70]. Some artificial physiological damage to the roots, such as pretreatment with $\mathrm{HCl}$, methanol: trichloromethane (MC) and hot water, and treatment with 2,4-dinitrophenol (DNP) could dramatically enhance $\mathrm{Pb}$ phytoextraction alongside EDTA application [71-72]. Luo et al. [39] found that metal phytoextraction efficiency improved greatly when the chelants were applied as hot solutions at the same dosage. Environmental stresses such as excessive toxic metals, high temperatures, and drought, might also result in a breakdown of the root exclusion mechanisms, subsequently affecting the chelant-enhanced accumulation of metals in plant shoots [38]. The encapsulation of chelants in slow-release formulas can slow down the mobilization of metals in the soil to match the uptake rate of plants, thus reducing the risk of metal leaching [73-74]. In addition, laying some active substance (such as sawdust, vermiculite, apatite, or biomass) in the subsoil can effectively prevent the leaching of heavy metals to the lower soil [75-76]. It is suggested that plants with timely chelant application and controlled deficit irrigation can enhance sediment cleanup while minimizing the leaching of metal complexes [51].

\section{Conclusions}

Chelant-induced phytoextraction has received much attention as one of the efficient techniques for the remediation of metal-contaminated soils. Based on the experimental studies reviewed in this paper, it is possible to conclude that the use of biodegradable chelants that are not persistent and are less harmful to the environment is recommended for chelant-induced phytoextraction. The application of chelants during the phytoextraction process has a negative impact on plants, soil quality, and even human health. The optimization of this technique using the appropriate choice of chelants, plant species, and 
application methods is necessary to increase its efficiency and decrease environmental risk.

Finally, there is a need for further research on chelantinduced phytoextraction for the discovery and synthesis of new mobilizing agents that would be effective as well as environmentally safe. The isolation and incubation of chelant-degrading bacteria is also crucial for accelerating the degradation of chelants after phytoextraction. Chelantinduced phytoextraction should be combined with other remediation techniques to increase phytoextraction efficiency and reduce environmental risks. Therefore, besides the basic research on chemical properties, more field studies are needed to understand the potential risks of these techniques. These improvements could increase the competitiveness of chelant-induced phytoextraction as a remediation technique for contaminated soil.

\section{Acknowledgements}

The work described here was supported by a project of the Natural Science Foundation of Jiangsu Province (No. BK20130499), the Natural Science Foundation of the Education Department of Jiangsu Province (Nos. 15KJB230003 and 16KJB180030), Yancheng Agricultural Science and Technology (Nos. YKN2013013 and 2014019), and the Foundation of Jiangsu Key Laboratory for Bioresources of Saline Soils (Nos. JKLBS2013011 and 2014010).

\section{References}

1. TSANG D.C.W., YIP T.C.M., LO I.M.C. Simulation of kinetic extraction of heavy metals during chelant-enhanced soil washing. J Soil Sediment. 11, 1221, 2011.

2. ZHAO Y., MAO G., XIA H.H., GAO L. Effects of EDTA and EDDS on Heavy Metal Activation and Accumulation of Metals by Soybean in Alkaline Soil. Soil Sediment Contam. 24, 353, 2015.

3. FABBRICINO M., FERRARO A., DEL GIUDICE G., D'ANTONIO L. Current views on EDDS use for ex situ washing of potentially toxic metal contaminated soils. Rev Environ Sci Bio. 12, 391, 2013.

4. KRAMER U. Metal Hyperaccumulation in Plants, in: Merchant, S., Briggs, W.R., Ort, D. (Eds.). Annu Rev Plant Biol. 61, 517, 2010.

5. XIA B.C., SHEN S.L., XUE F. Phytoextraction of heavy metals from highly contaminated soils using Sauropus androgynus. Soil Sediment Contam. 22, 631, 2013.

6. PADMAPRIYA S., MURUGAN N., RAGAVENDRAN C., THANGABALU R., NATARAJAN D. Phytoremediation Potential of some Agricultural Plants on Heavy Metal Contaminated Mine Waste Soils, Salem District, Tamilnadu. Int J Phytoremediat. 18, 288, 2016.

7. LUO C.L., SHEN Z.G., LOU L.Q., LI X.D. EDDS and EDTA-enhanced phytoextraction of metals from artificially contaminated soil and residual effects of chelant compounds. Environ Pollu. 144, 862, 2006.

8. MENCH M., LEPP N., BERT V., SCHWITZGUÉBEL J.P., GAWRONSKI S.W., SCHRÖDER P., VANGRONSVELD J. Successes and limitations of phytotechnologies at field scale: outcomes, assessment and outlook from COST Action 859. J Soil Sediment. 10, 1039, 2010.

9. RAMAMURTHY A.S., MEMARIAN R. Chelate enhanced phytoremediation of soil containing a mixed contaminant. Environ Earth Sci. 72, 201, 2013.

10. NOWACK B., SCHULIN R., ROBINSON B.H. Critical Assessment of Chelant - Enhanced Metal Phytoextraction. Environ Sci Technol. 40, 5225, 2006.

11. EVANGELOU M.W.H., BAUER U., EBEL M., SCHAEFFER A. The influence of EDDS and EDTA on the uptake of heavy metals of $\mathrm{Cd}$ and $\mathrm{Cu}$ from soil with tobacco Nicotiana tabacum. Chemosphere. 68, 345, 2007.

12. YANG L., WANG G.P., CHENG Z.N., LIU Y., SHEN Z.G., LUO CL. Influence of the application of chelant EDDS on soil enzymatic activity and bacterial community composition. J Hazard Mater. 262, 561, 2013.

13. SHE W., CUI G.X., JIE Y.C., BAI Y.C., CAO Y., XIAO C.X. Comparative effects of chelants on plant growth, cadmium uptake and accumulation in nine cultivars of Ramie (Boehmeria nivea). Acta Agr Scand B-S P. 64, 71, 2014.

14. YEH T.Y., LIN C.L., LIN C.F., CHEN C.C. Chelatorenhanced phytoextraction of copper and zinc by sunflower, Chinese cabbage, cattails and reeds. Int J Sci Technol. 12, 327, 2015.

15. LEE J.H., SUNG K.J. Effects of chelates on soil microbial properties, plant growth and heavy metal accumulation in plants. Ecol Eng. 73, 386, 2014.

16. GHOSH M., SINGH S.P. A review on phytoremediation of heavy metals and utilization of it's by products. Asian J Energy Environ. 6 (4), 18, 2005.

17. WANG H.Q., LU S.J., LI H., YAO Z.H. EDTA-enhanced phytoremediation of lead contaminated soil by Bidens maximowicziana. J Environ Sci-China. 19, 1496, 2007.

18. CHANEY R.L., BROADHURST C.L., CENTOFANTI T. Phytoremediation of soil trace elements. In: Hooda, P.S. (Ed.), Trace Elements in Soils. Blackwell Publishers, Oxford, UK, 311, 2010.

19. ÁLVAREZ-LÓPEZ V., PRIETO-FERNÁNDEZ Á., CABELLO-CONEJO M.I., KIDD P. Organic amendments for improving biomass production and metal yield of Ni-hyperaccumulating plants. Sci Total Environ. 548-549, 370, 2016.

20. BOLAN N., KUNHIKRISHNAN A., THANGARAJAN R., KUMPIENE J., PARK J., MAKINO T., KIRKHAM M.B., SCHECKEL K. Remediation of heavy metal (loid) $\mathrm{S}$ contaminated soils-to mobilize or to immobilize? J Hazard Mater. 266, 141, 2014.

21. POLLARD A.J., REEVES R.D., BAKER A.J.M. Facultative hyperaccumulation of heavy metals and metalloids. Plant Sci. 217-218, 8, 2014.

22. EBBS S.D., LASAT M.M., BRADYR D.J., CORNISH J., GORDON R., KOCHIAN L.V. Phytoextraction of cadmium and zinc from a contaminated site. J Environ Qual. 26, 1424, 1997.

23. KIDD P., MENCH M., ÁLVAREZ-LÓPEZ V., BERT V., DIMITRIOU I., FRIESL-HANL W., HERZIG R., JANSSEN J.O., KOLBAS A., MULLER I. Agronomic practices for improving gentle remediation of trace elementcontaminated soils. Int J Phytoremediat. 17, 1005, 2015.

24. MAHAR A., WANG P., ALI A., AWASTHI M.K., LAHORI A.H., WANG Q., LI R.H., ZHANG Z.Q. Challenges and opportunities in the phytoremediation of heavy metals contaminated soils: A review. Ecotox Environ Safe. 126, 111,2016

25. HUANG J.W., CHEN J., BERTI W.R., ENSLEY B.D. 
Phytoremediation of lead-contaminated soils: role of synthetic chelates in lead phytoextraction. Environ Sci Technol. 31, 800, 1997.

26. NOWACK B., VANBRIESEN J.M. In Biogeochemistry of Chelating Agents, American Chemical Society: Washington, DC, 204, 2005.

27. SALT D.E., BLAYLOCK M., KUMAR PBAN, DUSHENKOV V., ENSLEY B.D., CHET I., RASKIN I. Phytoremediation: A novel strategy for the removal of toxic metals from the environment using plants. Nat Biotechnol. 13, 468, 1995.

28. ARWIDSSON Z., ALLARD B.. Remediation of metal-contaminated soil by organic metabolites from fungi II: Metal redistribution. Water Air Soil Poll. 207, 5, 2010.

29. NOWACK B. Environmental chemistry of aminopolycarboxylate chelating agents. Environ Sci Technol. 36, 4009, 2002.

30. ZHANG W., TSANG D.C.W. Conceptual framework and mathematical model for the transport of metal-chelant complexes during in-situ soil remediation. Chemosphere. 91, 1281, 2013.

31. SARRET G., VANGRENSVELD J., MANCEAU A., MUSSO M., D'HAEN J., MENTHONNEX J.J., HAZEMANN J.L. Accumulation forms of $\mathrm{Zn}$ and $\mathrm{Pb}$ in Phaseolus vulgaris in the presence and absence of EDTA. Environ Sci Technol. 35, 2854, 2001.

32. WEI L., LUO C.L., WANG C.C., LI X.D., SHEN Z.G. Biodegradable chelating agent ethylenediamine disuccinic acid reduces uptake of copper through alleviation of copper toxicity in hydroponically grown Chrysanthemum coronarium L. Environ Toxicol Chem. 26, 749, 2007.

33. FU Y.Z., LEI W.R., SHEN Z.G., LUO C.L. Permeability of Plant Young Root Endodermis to $\mathrm{Cu}$ Ions and $\mathrm{Cu}$-Citrate Complexes in Corn and Soybean. Int J Phytoremediat. 17, 822, 2015.

34. TANDY S., SCHULIN R., NOWACK B. Uptake of metals during chelant-assisted phytoextraction with EDDS related to the solubilized metal concentration. Environ Sci Technol. 40, 2753, 2006.

35. TIAN S.K., LU L.L., YANG X.E., WEBB S.M., DU Y.H., BROWN P.H. Spatial imaging and speciation of lead in the accumulator plant sedumalfredii by microscopically focused synchrotron X-ray investigation. Environ Sci Technol. 44, 5920, 2010.

36. BELL P.F., CHANEY R.L., ANGLE J.S. Free metal activity and total metal concentrations as indexes of micronutrient availability to barley. Plant Soil. 130, 51, 1991.

37. NIU L.Y., SHEN Z.G., WANG C.C. Sites, pathways, and mechanism of absorption of Cu-EDDS complex in primary roots of maize (Zea Mays L.): anatomical, chemical and histochemical analysis. Plant Soil. 343, 303, 2011.

38. LEŠTAN D., LUO C.L., LI X.D. The use of chelating agents in the remediation of metal-contaminated soils: A review. Environ Pollut. 153, 3, 2008.

39. LUO C.L., SHEN Z.G., LI X.D. Hot NTA application enhanced metal phytoextraction from contaminated soil. Water Air Soil Poll. 188, 127, 2008.

40. GRČMAN H., VODNIK D., VELIKONJA-BOLTA S., LEŠTAN D. Ethylenediamine Dissuccinate as a new chelate for environmentally safe enhanced lead phytoextraction. J Environ Qual. 32, 500, 2003.

41. LAI H.Y. Negative Effects of Chelants on Soil Qualities of Five Soil Series. Int J Phytoremediat. 17, 228, 2015.

42. ULTRA V.U., YANO A., IWASAKI K., TANAKA S., MEI
K.Y., SAKURAI K. Influence of chelating agent addition on the copper distribution and microbial activity in soil and copper uptake by brown mustard (Brassica juncea). Soil Sci Plant Nutr. 51, 193, 2005.

43. SATO K., NAKAMURA Y., OHTSUKI K. Different arrangement of $\varepsilon-(\gamma$-glutamyl)lysine cross-linking in Alaska Pollock (Theragra chalcogremma) surimi proteins by Streptoverticillium and endogenous transglutaminases during suwari process. J Food Biochem. 25, 397, 2001.

44. EPELDE L., HERNANDEZ-ALLICA J., BECERRIL J.M., BLANCO F., GARBISU G. Effects of chelates on plants and soil microbial community: Comparison of EDTA and EDDS for lead phytoextraction. Sci Total Environ. 401, 21, 2008.

45. YANG L., LUO C.L., LIU Y., QUAN L.T., CHEN Y.H., SHEN Z.G. Residual effects of EDDS leachates during EDDS-assisted phytoremediation of copper contaminated soil. Sci Total Environ. 444, 263, 2013.

46. SAPOUNDJIEVA K., KARTALSKA Y., VASSILEV A., NAIDENOV M., KUZMANOVA I., KRASTEV S. Effects of the chelating agent EDTA on metal solubility in the soil, metal uptake and performance of maize plants and soil microorganisms. Bulg J Agric Sci. 9, 659, 2003.

47. VAMERALI T., BANDIERA M., LUCCHINI P., MOSCA G. Metal partitioning in plant-substrate-water compartments under EDDS-assisted phytoextraction of pyrite waste with Brassica carinata A. Braun. Environ Sci Pollut R. 22, 2434, 2015.

48. MICHAEL W.H., EVANGELOU U.B., MATHIAS E., ANDREAS S. The influence of EDDS and EDTA on the uptake of heavy metals of $\mathrm{Cd}$ and $\mathrm{Cu}$ from soil with tobacco Nicotiana tabacum. Chemosphere. 68, 345, 2007.

49. JEAN F., BORDAS F., BOLLINGER J.C. Column leaching of chromium and nickel from a contaminated soil using EDTA and citric acid. Environ Pollut. 164, 175, 2012.

50. WANG A.G., LUO C.L., YANG R.X., CHEN Y.H., SHEN Z.G., LI X.D. Metal leaching along soil profiles after the EDDS application-a field study. Environ Pollut. 164, 204, 2012.

51. FINE P., PARESHA R., BERIOZKINA A., HASS A. Chelant-enhanced heavy metal uptake by Eucalyptus trees under controlled deficit irrigation. Sci Total Environ. 493, 995, 2014.

52. CHEN F., TAN M., MA J., LI G. QU J.F. Restoration of manufactured gas plant site soil through combined ultrasound-assisted soil washing and bioaugmentation. Chemosphere. 146, 289, 2016.

53. MEERS E., RUTTENS A., HOPGOOD M.J., SAMSON D., Tack FMG. Comparison of EDTA and EDDS as potential soil amendments for enhanced phytoextraction of heavy metals. Chemosphere. 58, 1011, 2005.

54. SCHOWANEK D., FEIJTEL T.C.J., PERKINS C.M., HARTMAN F.A., FEDERLE T.W., LARSON R.J. Biodegradation of S, S, R, R and mixed stereoisomers of ethylene diamine disuccinic acid (EDDS), a transition metal chelator. Chemosphere. 34, 2375, 1997.

55. JAWORSKA J.S., SCHOWANEK D., FEIJTEL T.C.J. Environmental risk assessment for trisodium [S, S]ethylene diamine disuccinate, a biodegradable chelator used in detergent applications. Chemosphere. 38, 3597, 1999.

56. HAUSER L., TANDY S., SCHULIN R., NOWACK B. Column extraction of heavy metals from soils using the biodegradable chelating agent EDDS. Environ Sci Technol. 39, 6819, 2005.

57. VANDEVIVERE P.C., SAVEY H., VERSTRAETE W., 
FEIJTEL T.C., SCHOWANEK D.R. Biodegradation of metal-[S, S]-EDDS complexes. Environ Sci Technol. 35, 1765, 2001.

58. LUO C.L., SHEN Z.G., LI X.D. Enhanced phytoextraction of $\mathrm{Cu}, \mathrm{Pb}, \mathrm{Zn}$ and $\mathrm{Cd}$ with EDTA and EDDS. Chemosphere. 59, 1,2005

59. MEERS E., TACK F.M.G, VERLOO M.G. Degradability of ethylenediaminedisuccinic acid (EDDS) in metal contaminated soils: implications for its use soil remediation. Chemosphere. 70, 358, 2008.

60. LO I.M.C., TSANG D.C.W., YIP T.C.M., WANG F., ZHANG W.H. Significance of metal exchange in EDDSflushing column experiments. Chemosphere. 83, 7, 2011.

61. SHEN Z.G., CHEN H.M. Phytoremediation and heavy metal hyperaccumulator, China Agricultural University press, Beijing, 216, 2000.

62. PASTOR J., APARICIO A.M., GUTIERREZ-MAROTO. Effects of two chelating agents (EDTA and DTPA) on the autochthonous vegetation of a soil polluted with $\mathrm{Cu}, \mathrm{Zn}$ and Cd. Sci Total Environ. 378, 114, 2007.

63. KOMÁREK M., VANEK A., MRNKA L., SUDOVÁ R., SZÁKOVÁ R., TEJNECKÝ V., CHRASTNÝ V. Potential and drawbacks of EDDS-enhanced phytoextraction of copper from contaminated soils. Environ Pollut. 158, 2428, 2010.

64. TSANG D.C.W., YIP T.C.M., LO I.M.C. Kinetic interactions of EDDS with soils. 2. Metal-EDDS complexes in uncontaminated and metal-contaminated soils. Environ Sci Technol. 43, 837, 2009.

65. CHEN X.T., WANG X., CHEN X. Study on the extraction efficiency of heavy metals by chelates. Jiangsu Environ Sci Technol. 18, 9, 13, 2005.

66. GUO H.Y., WANG W., SUN YY, LI H., AI F.X., XIE L., WANG X.R. Ethyllactate enhances ethylenediamine disuccinic acid solution removal of copper from contaminated soils. J Hazard Mater. 174, 59, 2010.

67. HU Y.H., WEI S.H., ZHOU Q.X., ZHAN J., MA L.H., NIU R.C., LI Y.Y., WANG S.. Application of Chelator in Phytoremediation of Heavy Metals Contaminated Soils: A Review. J Agro-Environ Sci. 29, 2055, 2010.

68. CHEN Y.H., LI X.D., SHEN Z.G. Leaching and uptake of heavy metals by ten different species of plants during an EDTA-assisted phytoextraction process. Chemosphere. 57, 187, 2004.

69. LINGUA G., TODESCHINI V., GRIMALDI MICHELE, BALDANTONI D., PROTO A., CICATELLI A., BIONDI S., TORRIGIANI P., CASTIGLIONE S. Polyaspartate, a biodegradable chelant that improves the phytoremediation potential of poplar in a highly metal-contaminated agricultural soil. J Environ Manage. 132, 9, 2014.

70. CHEN Z.J., SHENG X.F., HE L.Y., HUANG Z., ZHANG W.H. Effects of root inoculation with bacteria on the growth, Cd uptake and bacterial communities associated with rape grown in Cd-contaminated soil. J Hazard Mater. 244-245, 709, 2013.

71. LUO C.L., SHEN Z.G., BAKER A.J.M., LI X.D. A novel strategy for chemically enhanced phytoremediation of heavy metal-contaminated soils. Plant Soil. 285, 67, 2006.

72. CHEN Y.H., WANG C.C., WANG G.P., LUO C.L., MAO Y., SHEN Z.G., LI X.D. Heating treatment schemes for enhancing chelant-assisted phytoextraction of heavy metals from contaminated soils. Environ Toxicol Chem. 27, 888, 2008.

73. LI H.F., WANG Q.R., CUI Y.S., DONG Y.T., CHRISTIE P. Slow release chelate enhancement of lead phytoextraction by corn (Zea mays L.) from contaminated soil-a preliminary study. Environ Pollut. 339, 179, 2005.

74. XIE Z., WU L., CHEN N., LIU C., ZHENG Y., XU S.G., LI F.B., $\mathrm{XU}$ Y.L. Phytoextraction of $\mathrm{Pb}$ and $\mathrm{Cu}$ contaminated soil with maize and microencapsulated EDTA. Int J Phytoremediat. 14, 727, 2012.

75. KOS B., LEŠTAN D. Soil washing of $\mathrm{Pb}, \mathrm{Zn}$ and $\mathrm{Cd}$ using biodegradable chelator and permeable barriers and induced phytoextraction by Cannabis sativa. Plant Soil. 263, 43, 2004.

76. YANG L., JIANG L.F., WANG G.P., CHEN Y.H., SHEN Z.G., LUO C.L. Assessment of amendments for the immobilization of $\mathrm{Cu}$ in soils containing EDDS leachates. Environ Sci Pollut R. 22, 16525, 2015. 